\title{
Mechanized pollen harvesting with a view to hybrid larch seed production
}

\author{
G Philippe, P Baldet
}

\begin{abstract}
CEMAGREF, Division Amélioration Génétique et Pépinières Forestières, Domaine des Barres, 45290 Nogent-sur-Vernisson, France
\end{abstract}

(Received 12 December 1990; accepted 2 March 1992)

\begin{abstract}
Summary - The phenological lag that exists between flowering of European (Larix decidua Mill) and Japanese (Larix leptolepis Gord) larch clones present in French seed orchards is too great to allow hybrid seed production. Artificial pollination is thus required. This necessitates collection of large amounts of pollen from the Japanese larch grafts which are used as the male parent. To obtain sustained production at a reasonable price, we attempted to collect pollen (directly from the grafts) mechanically. First, pollen is forced to shed by whipping the tree enclosed in a tight-fitting tank fixed in front of a tractor. Then, pollen is sucked backwards where it is filtered and collected. Despite certain restrictions connected with mechanical harvesting (such as the impossibility to harvest in rainy weather, and having to prune the trees so that they fit the size of the tank) the results of the first 3 harvesting campaigns have proved very successful. When the atmospheric conditions are good, the grafts are harvested 5 times, each harvest requiring 1.5 minutes. The seed orchard in which mechanical harvesting was tested includes 14014 -year-old grafts, 3 metres high. These clones respectively provided $90 \mathrm{~g}, 450 \mathrm{~g}$ and $1.3 \mathrm{~kg}$ of dry pollen in 1988, 1989 and 1990 . So at least 2 years out of 3 the harvester enabled rapid collection of large quantities of pollen by only 1 or 2 workers in a conventional seed orchard. Moreover, it seems obvious this technique would be particularly suited to indoor seed orchards.
\end{abstract}

harvesting / pollen / seed orchard / genetic improvement / Larix leptolepis = larch

Résumé - Récolte mécanisée de pollen de mélèze en vue de l'obtention de graine hybride. L'existence d'un décalage phénologique entre les floraisons des clones de Larix leptolepis et du clone de Larix decidua installés en verger à graines pour la production de graine hybride implique l'artificialisation de l'hybridation et, en premier lieu, la récolte de pollen sur le parent mâle (Larix leptolepis Gord). Les méthodes traditionnelles, consistant à prélever des strobiles mâles ou des rameaux florifères puis à extraire le pollen en laboratoire, n'ont pas été jugées compatibles avec une production abondante et régulière. II est apparu au contraire qu'il convenait de récolter le pollen directement sur les arbres et que, seule la mécanisation de cette intervention permettrait d'obtenir les quantités de pollen requises à un coût raisonnable. Aussi un prototype a-t-il vu le jour en 1986. Porté sur tracteur agricole, il comporte à l'avant une cuve étanche munie de "flagelles", que l'on positionne autour de l'arbre à récolter, et qui autorise l'extraction du pollen en milieu clos, par se-

\footnotetext{
${ }^{\star}$ Correspondence and reprints
} 
couage. Ce dernier, en suspension dans l'air, est ensuite aspiré vers la partie arrière du tracteur où sont situés le dispositif de filtration et les trémies de récupération. Grâce à cet appareil, 3 campagnes de récolte ont pu être réalisées dans un verger expérimental renfermant 140 plants greffés de 14 ans, d'une hauteur moyenne de $3 \mathrm{~m}$. Le bilan se révèle très positif puisqu'elles ont procuré $90 \mathrm{~g}, 450 \mathrm{~g}$ et $1,3 \mathrm{~kg}$ de pollen sec respectivement en 1988 (année caractérisée par une faible floraison), 1989 et 1990. Lorsque les conditions atmosphériques sont favorables, chaque arbre est récolté 5 fois en moyenne, chaque passage nécessitant $1,5 \mathrm{~min}$. Cependant, cette réussite incontestable ne doit pas occulter les contraintes qu'impose l'utilisation de l'aspirateur à pollen. Dans sa configuration actuelle, il ne dispose pas d'une stabilité suffisante en terrain pentu (limite maxi estimée à 10-12\%). En outre, l'opérateur demeure tributaire des conditions atmosphériques régnant lors de la pollinisation, la pluie en particulier interdisant les récoltes. Enfin, le principe retenu implique une taille périodique des arbres de manière à ce que leurs dimensions soient compatibles avec celles de la cuve. Cette dernière intervention pourrait néanmoins être mise à profit pour accroître leur potentiel florifère en favorisant l'apparition de rameaux porteurs de strobiles mâles. Toutefois, ces inconvénients sont sans importantce dans le cas de vergers sous serre et, au vu des résultats enregistrés en plein-champ, il est évident que la technique décrite dans cet article constituerait un outil parfaitement adapté à ce nouveau type de verger.

récolte mécanique / pollen / verger à graines / amélioration génétique / Larix leptolepis = mélèze

\section{INTRODUCTION}

Among the species included in the French State Seed Orchard Program, some are insufficiently used in afforestation due to a lack of good quality seed, and require specific efforts by the seed orchard managers. This is he case of hybrid larch (Larix eurolepis Henry), well known for its high productivity. In particular, the offspring of the clones established in the French seed orchards show clear superiority compared with parent species, especially for growth vigor, trunk straightness, adaptability and wood mechanical properties (Steinmetz and Baldet, 1987). The earliest test indicates a $16.7 \mathrm{~m}^{3}$. ha- $\mathrm{a}^{-1}$.year-1 mean volume increment 26 years after planting compared to 12.8 for Japanese and 10.3 for European larch (Ferrand and Bastien, 1985).

However, hybridization seed orchards present specific problems. In particular, phenological lags between the 2 species can prevent effective wind pollination and lead to artificial hybridization. This implies the successful outcome of 3 separate operations: pollen harvesting on the male parent, its storage after adequate drying and processing, and finally, pollination of the species used as female.

As far as pollen harvesting is concerned, the usual method consists of manual picking of male strobili on the grafts. However, this is time-consuming if one considers that the pollination of 1 hectare of seed orchard requires the collection of several $\mathrm{kg}$ of pollen and therefore several hundred thousand strobili. It is possible to save time by cutting flowering branches but, as larch bears its flowers on at least 2year-old branches, this pruning leads to the elimination of potentially flowering short shoots the following year and does not seem compatible with sustained production. Our solution was to collect the pollen directly on the grafts and to mechanize this operation in an attempt to reduce its cost. The construction of a prototype began in 1986. At that time, no mention could be found in the literature about mechanical harvesting of pollen. However, more re- 
cently, Copes et al (1991) also noted that only limited quantities of pollen could be collected in Douglas fir seed orchards with available collection equipment and built a cyclone machine to vacuum pollen from large trees.

The pollen harvester we will describe in this paper has been operating satisfactorily for 3 consecutive years. The experience acquired permits a preliminary estimation regarding the efficiency of the technique.

\section{MATERIALS AND METHODS}

\section{Technical aspects of the mechanical harvester}

The machine is built onto an agricultural tractor (figs 1, 2). It consists of 2 main parts:

- a tank, $2.5 \mathrm{~m}$ in diameter and $3 \mathrm{~m}$ high, which can be opened and shut so that it encloses the tree to be harvested. It is made of transparent plastic material which allows a good view of the operation;

- a rear unit combining the components for vacuum pumps, filtration and pneumatic energy production.

The technique is based on the anemophilous character of larch pollination. Harvesting consists of 3 different stages:

- pollen is shaken out of the male flowers by whipping the tree. Short blasts of compressed air are blown through 12 semi-rigid pipes fastened on the lateral walls of the tank. Under the effect of air pressure $\left(8-10 \mathrm{~kg} \cdot \mathrm{cm}^{-2}\right)$ these pipes whip the tree vigourously so that it releases its pollen;

- pollen in suspension within the tank is sucked backwards into the filtration unit (flow rate of about $4000 \mathrm{~m}^{3} \cdot \mathrm{h}^{-1}$ ). Larch pollen naturally carries a static charge and adheres strongly to any surface it comes into contact with. To increase yield, the tank has been equipped with an antisticking device consisting of air streams which line the lateral walls of the tank and arry the pollen towards 4 sucking holes located on the floor. These holes then connect up with 2 pipes
(250 $\mathrm{mm}$ in diameter) which link the harvesting tank to the suction-filtration unit. The pipes have an internal ringed surface which also helps minimize pollen loss through sticking;

- pollen in suspension is filtered through 11 filtration sleeves, each $1 \mathrm{~m}^{2}$ made of single-thread nylon (37-micron welded mesh). This tissue replaced a more fibrous filtration material used during the first tests from which it was difficult to remove the pollen. The current filters are very smooth and with the assistance of a vibrator $(10-15 \mathrm{kHz})$ allow nearly complete recovery of the pollen in hoppers fixed at the bottom of the filtration sieeves.

\section{Description of the seed orchard}

The machine was tested in a small experimental hybridization seed orchard with trees of Danish origin (FH 201) located at "Les Barres" in the centre of France. It consists of 4 rows of one European larch clone (coded V44) alternating with 5 rows, $5 \mathrm{~m}$ apart, of Japanese larch. The latter, used as the male parent, is made up of 56 related clones (inbreeding coefficient: 0.375 ). Grafts were planted in the field in 1976/1977, at 5-m intervals per row for European larch and at 4-m intervals for Japanese larch. Nowadays, the average tree is $3 \mathrm{~m}$ high and $2 \mathrm{~m}$ wide but marked disparities in size may be observed. The most vigourous trees were pruned laterally in order to fit within the tank of the machine.

Among the 140 Japenese larch grafts included in the orchard, 70, 115 and 127 grafts respectively were mechanically harvested in 1988 , 1989 and 1990. After harvesting, the pollen was sifted (100 micron-mesh) then dried by laying down a thin layer of pollen on a filter paper placed on granulated silica gel. When it reached $5-7 \%$ moisture content, pollen was removed and stored at $-18^{\circ} \mathrm{C}$.

\section{RESULTS AND DISCUSSION}

\section{Machine output}

The first 3 harvesting campaigns in the whole seed orchard provided $90 \mathrm{~g}, 450 \mathrm{~g}$ 
and $1.3 \mathrm{~kg}$ of dry pollen respectively in 1988 (a poor flowering year), 1989 and 1990. The average output per harvested graft was respectively $1.3 \mathrm{~g}, 3.9 \mathrm{~g}$ and $10.2 \mathrm{~g}$. The increase in production from 1988 to 1990 did not result from an improvement in the technique but rather from the steady increase in the number of male strobili produced. The knowledge acquired during the first 2 years did contribute to the success of the last harvesting, however. We should emphasize that whipping the trees leads to the release of strobili as well as pollen. In 1990, the pollen extracted

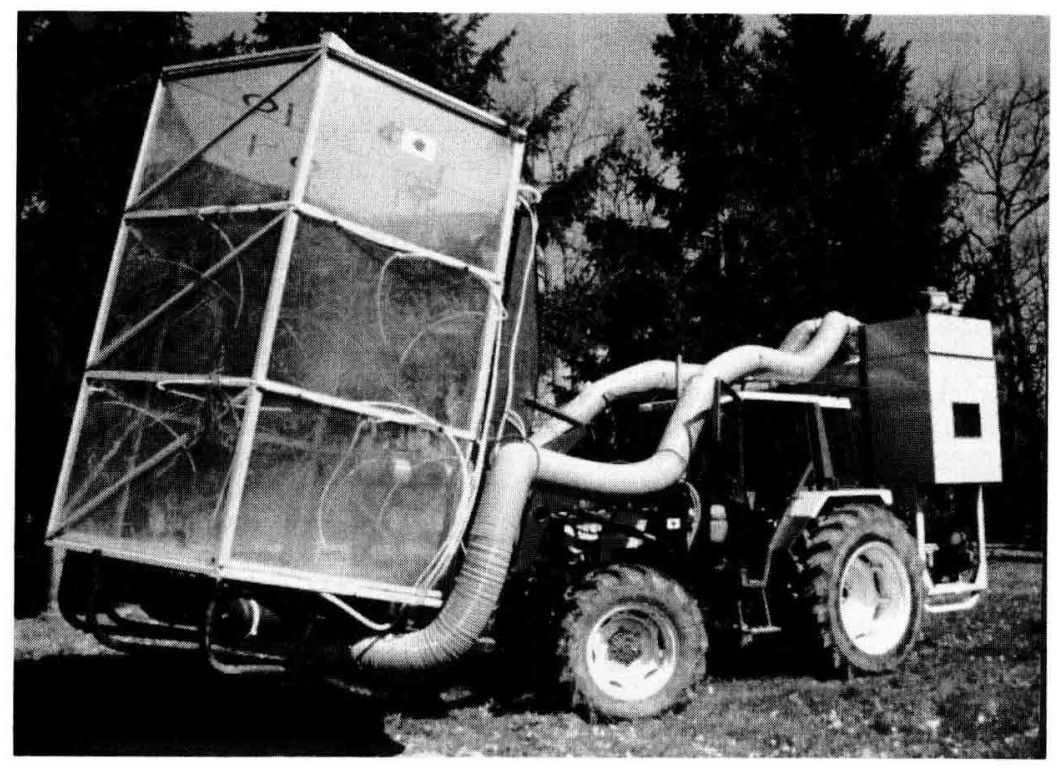

a

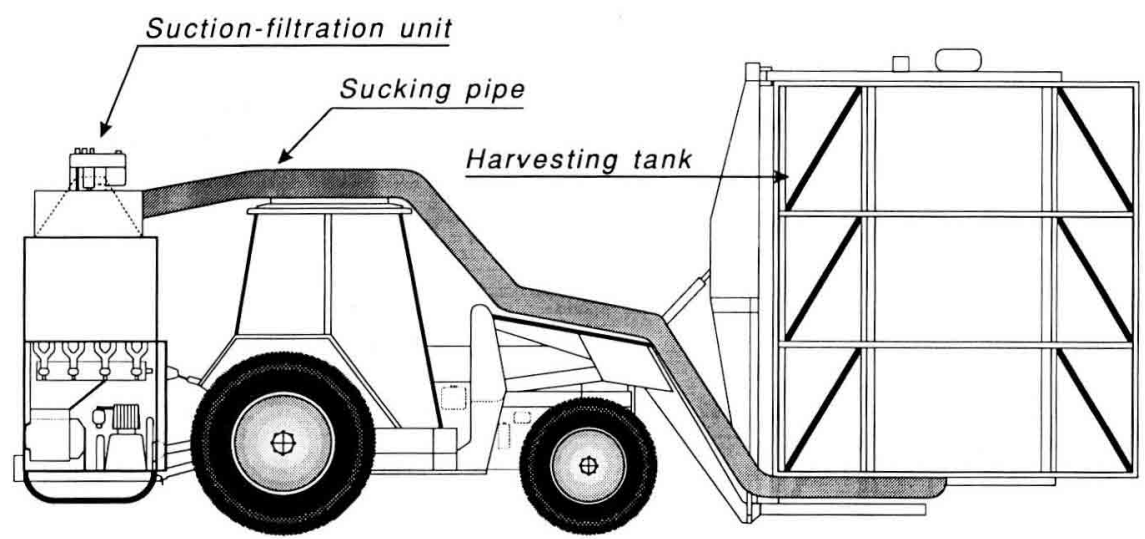

b

Fig 1. a. Pollen harvester during the "whipping" phase. b. Diagram of pollen harvester. 
from the male catkins separated from the trees after whipping constituted $20 \%$ of the whole crop.

On a seed orchard scale, the duration of pollen shedding varies from year to year according to weather conditions (fig 2). In 1989 and 1990, years which were characterized by high temperatures during the pollination period $\left(t_{\mathrm{m}}=0.5\left(t_{\max }+t_{\min }\right)=\right.$ $9.3{ }^{\circ} \mathrm{C}$ and $11.9{ }^{\circ} \mathrm{C}$ respectively), pollen was harvested in 1 week. On the other hand, in $1988\left(t_{\mathrm{m}}=3.1^{\circ} \mathrm{C}\right)$, the occurrence of a cold period considerably slowed down the development of the male gametophytes and delayed anthesis of the late clones. Finally, the last harvesting took place more than 3 weeks after the first.

In warm weather, the average tree sheds its pollen in about 1 week. Under

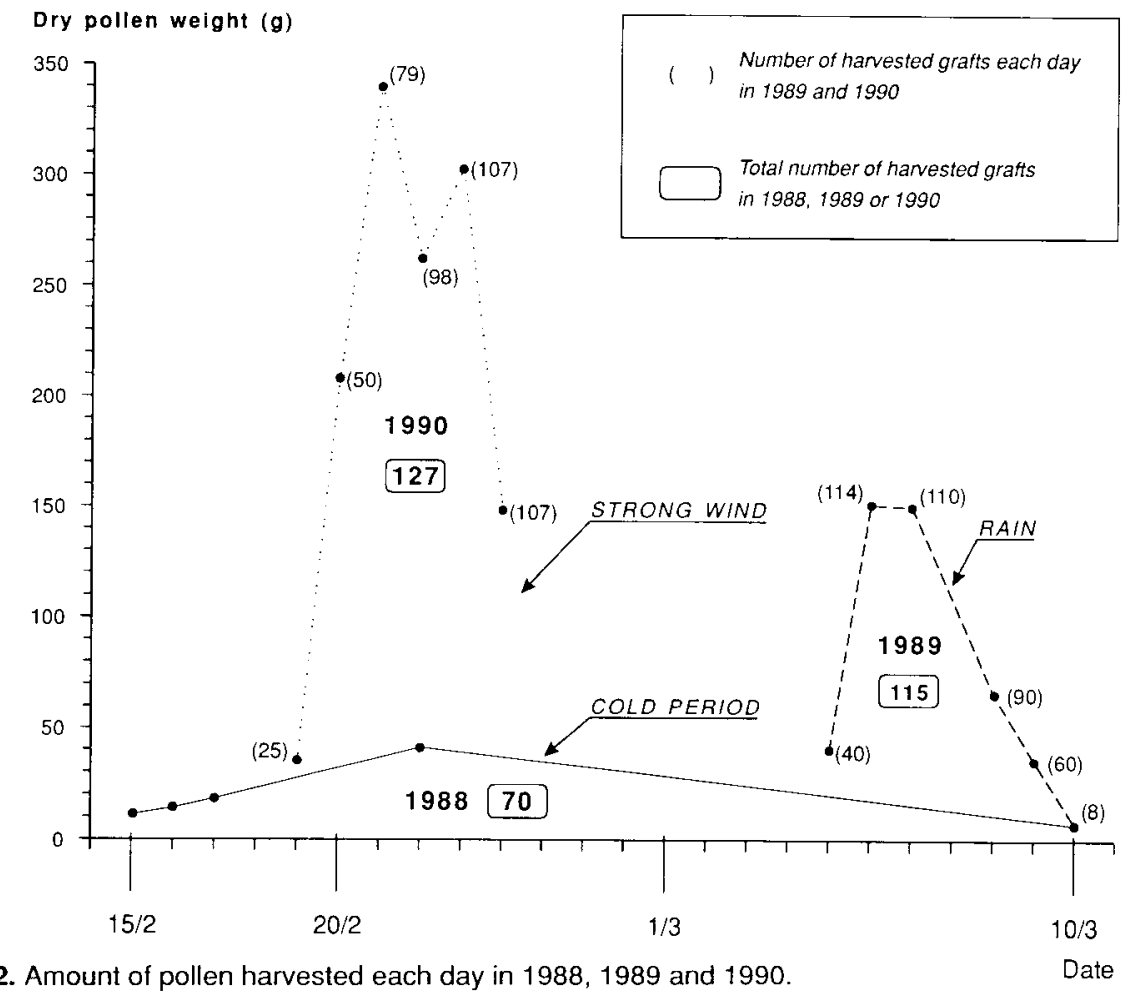

such conditions, in 1989 and 1990, each graft provided with a sufficient flower production was mechanically harvested 5 times on the average. For a skilled driver, each harvest requires $1.5 \mathrm{~min}$ including travel between trees, tank positioning and actual pollen harvesting. Though driving the machine needs only one operator, the help of an additional worker who identifies and points out beforehand the grafts ready for harvesting proves very useful.

\section{Restrictions due to the mechanization}

The principle of this mechanical harvesting device requires that pollen extraction and exhaustion take place in a closed environment. The size of the grafts, therefore,
Fig 2. Amount of pollen harvested each day in 1988, 1989 and 1990. 
must be compatible with the size of the harvesting tank. Periodic pruning is thus imperative. This height and width control may be initially considered as a serious disadvaıttage since smaller individuals (3$4 \mathrm{~m}$ high) have obviously lower flowering potentials than non-pruned trees. However, the economic feasibility of harvesting adult trees which have to be climbed should be considered. Moreover, we will try to take advantage of the pruning and increase the trees' potentials by attempting to encourage the emergence of weak hanging shoots on which the male buds are preferentially initiated (Longman and Wareing, 1958).

Contrary to manual strobili or flowering branch collection, the mechanical harvesting cannot begin before pollen shedding. Its success depends on the atmospheric conditions prevailing during this short period, the main unfavourable factors being rain and wind.

Rainy weather, unfortunately frequent during the pollination period in France (February and March), prevents harvesting. Under these conditions, the greater part of the pollen grains stick to the drops that fall into the tank, the sucking pipes, and the filters, so that a very small percentage of pollen reaches the hoppers. The quality of this water-saturated pollen must also be questioned. So, it seems wiser not to harvest during or immediately after a shower. Practically speaking, work resumes when the machine and the trees are dry again.

The same is the case for dew, and one can rarely take advantage of the early and later hours of the day which would allow a longer working period. Effective harvesting generally takes place between 11 am and $6 \mathrm{pm}$.

Between harvestings, the wind is responsible for significant pollen losses. Though the first "whipping" forces the shedding of pollen which otherwise would not have been released under natural conditions, we noticed the trees may shed their pollen again only 2 hours after harvesting in sunny weather. That is why the most productive grafts are harvested twice a day when time permits. The second harvesting provides smaller quantities of pollen. However, it is profitable when carried out at the peak of pollination or in a good flowering year.

The harvester's characteristics impose other restrictions regarding seed orchard and graft accessibility. Though the harvesting tank has been the subject of special study in order to reduce its weight (about $450 \mathrm{~kg}$ ), the height of this piece of equipment and the positioning of the suctionfiltration unit lead to a rather high center of gravity, ie as high as $1.40 \mathrm{~m}$. This corresponds to a $16 \%$ angle of side-slip determined in static testing. From a practical point of view, it seems dangerous to let the machine move on more than 10-12\% transverse slopes. We have recently started to work on how to improve its stability on sloping ground.

Cost effectiveness of mechanical harvesting could be improved if planting density of the seed orchard is well adapted to easy driving of the harvester $(9 \mathrm{~m}$ in total length). In this respect, 8-m spacing between rows and $6 \mathrm{~m}$ between trees seems advisable. Nevertheless, if orchard spacing is increased to accomodate mechanical harvesting, one must be sure that the extra land cost does not negate the cost savings of harvesting.

Moreover, considering new seed orchard design specifically adapted to mechanical harvesting, the gathering within rows of ramets of the same clone or of clones that behave similarly from a phenological point of view would make collection more efficient. 


\section{CONCLUSION}

In spite of the above-mentioned restrictions, the results of the first 3 harvesting campaigns appear very positive since large amounts of pollen were collected, at least in 1989 and 1990. Moreover, if we argue by analogy with Douglas fir pollen standards, conductivity analyses tend to prove that the technique does not damage the pollen. Still, we must emphasize that the 1990 flowering was heavy and the weather conditions proved favourable for mechanical harvesting. So the yield registered this year (10.2 $\mathrm{g}$ of dry pollen per harvested graft) can be considered an optimum for trees of that size growing in the field using this technique.

It is difficult to compare mechanical harvesting with manual methods for male strobili or flowering branch collection, since these techniques have never been used during the same year in the same orchard. Still, mechanical harvesting provides 2 advantages. First, only 2 workers, or even one, can rapidly collect large quantities of pollen when flowering is abundant. For instance, in 1990, $60 \mathrm{~g}$ of dry pollen were harvested per working hour. This corresponds to the production of 4 male strobili every second. Secondly, pollen is collected without pruning. The trees conserve their potential for subsequent years' flowering assuming, of course, that the graft size remains compatible with that of the machine.

With regards to this latter point, height control demanded by mechanization when the seed orchard grows old can be seen as a disadvantage. It is also true that the efficiency of the technique depends on the atmospheric conditions prevailing during pollination. Nevertheless, these restrictions are of no importance if one considers indoor seed orchards, designed to accomodate small potted grafts safe from wind and rain. It is obvious that the harvester described in this paper would be particularly suited to this kind of orchard.

In the future, it will be advisable to search for and to develop techniques capable of intensifying Japanese larch pollen production, including hormonal and/or cultural treatments such as pruning. With regards to growth regulator application, Philipson (1990) emphasizes the variability of the results obtained.

Finally, pollen harvesting constitutes only the first stage in the process leading to hybrid seed production. Reapplication of pollen is now one of our major concerns. A new prototype is already being developed. It operates in a similar way to the harvester but acts in the reverse manner to pollinate the tree (Philippe and Terrasson, 1990).

\section{ACKNOWLEDGMENTS}

We express our gratitude to the CEMAGREF staff in Montoldre (France) who actively participated in the basic studies and in the construction of the prototype. We are also thankful to $M$ Bonnet-Masimbert for his advice and $\mathrm{J}$ Webber for reviewing the English manuscript.

\section{REFERENCES}

Copes DL, Vance NC, Randall WK, Jasumback A, Hallman R (1991) Vacuum Collection of Douglas Fir Pollen for Supplemental Mass Pollinations. US Dep Agric For Serv, Pacific NW Res Stat, Res Note PNW-RN-503, $8 p$

Ferrand JC, Bastien JC (1985) Bilan à 26 ans d'une plantation comparative de mélèzes. Rev For Fr 37, 441-448

Longman KA, Wareing PF (1958) Effect of gravity on flowering and shoot growth in Japanese larch (Larix leptolepis Murray). Nature (Lond) $182,379-381$ 
Philippe G, Terrasson D (1990) Intensification de la production de graines améliorées dans les vergers à graines français. In: Proc $X I X$ Congr Mondial IUFRO, Montreal, 5-1 1 August, vol $1,444-455$

Philipson JJ (1990) Prospects for enhancing flowering of conifers and broad leaves of po- tential silvicultural importance in Britain. Forestry $63,223-240$

Steinmetz G, Baldet P (1987) Production de Graines Hybrides de Mélèze : Récolte Mécanisée du Pollen. Inf Tech CEMAGREF, Cah 68 , No $4,7 p$ 